\title{
In vitro and in vivo evaluation of pharmacological potentials of Campsis radicans $\mathrm{L}$
}

Mirazul Islam, Tabassum Jannat, Md. Ruhul Kuddus, Mohammad Abdur Rashid and

Mohammad Rashedul Haque* (i)

\begin{abstract}
Background: Campsis radicans L. is a flowering plant in Bangladesh, traditionally used for the treatment of several human diseases. In this study, in vitro antioxidant, thrombolytic, membrane stabilizing and in vivo analgesic, hypoglycemic, anti-diarrheal and CNS antidepressant activities of organic soluble fractions of crude methanol extract of $C$. radicans leaf were investigated using appropriate experimental models.

Methods: The leaves of $C$. radicans were collected, authenticated, dried and extracted with methanol at room temperature for 30 days. The concentrated methanol extract was partitioned to petroleum-ether (PESF), dichloromethane (DMSF) and ethyl acetate (EASF) soluble fractions. The antioxidant activity of these fractions was determined by DPPH free radical scavenging method. Total phenolic content was determined by the Folin-Ciocalteau's spectrophotometric method. The thrombolytic activity was assessed by measuring clot lysis ability whereas the membrane stabilizing activity was evaluated by heat- and hypotonic solution-induced hemolysis assay. Tail immersion procedure and acetic acid-induced writhing model were used to measure the analgesic activity of C. radicans. The hypoglycemic, anti-diarrheal and CNS antidepressant activities were determined by oral glucose tolerance test, castor oil-induced diarrheal model and thiopental-sodium induced sleeping time test in mice, respectively.

Results: All the organic soluble fractions of C. radicans contained phenolic compounds varying from 6.38 to $60.13 \mathrm{mg}$ of GAE/gm of extractive, while in DPPH assay, EASF showed the highest free radical scavenging activity with $I_{50}$ is $4.69 \mu \mathrm{g} / \mathrm{ml}$. The PESF exhibited highest thrombolytic activity $(57.14 \%$ clot lysis) and the DMSF showed maximum 53.95\% inhibition of heat-induced hemolysis of human RBCs. In both tail immersion and acetic acid induced writhing models, the PESF, DMSF, EASF at the doses of 200 and $400 \mathrm{mg} / \mathrm{kg}$ body weight, induced a significant $(P<0.001)$ decrease in the painful sensation in mice. Substantial $(P<0.05)$ antihyperglycemic activity of test samples was found in mice loaded with glucose at the same doses mentioned earlier. Castor oil induced diarrheal test of the plant extractives has shown significant effect in comparison to control group. In CNS antidepressant activity assay, the test samples were able to reduce the duration of sleep in mice caused by thiopental administration.
\end{abstract}

Conclusion: All these findings revealed that C. radicans possess significant antioxidant, thrombolytic, membrane stabilizing, analgesic, hypoglycemic, anti-diarrheal and CNS antidepressant activities.

Keywords: Campsis radicans, Antioxidant, Thrombolytic, Membrane-stabilizing, Analgesic, Hypoglycemic, Antidiarrheal, CNS antidepressant

\footnotetext{
* Correspondence: haquemr@du.ac.bd

Phytochemical Research Laboratory, Department of Pharmaceutical

Chemistry, Faculty of Pharmacy, University of Dhaka, -1000, Dhaka,

Bangladesh
} 


\section{Background}

Developing a new drug involves identifying lead compounds with desired biological activity. Nature is a verified source of such lead compounds having anticancer, antimicrobial, analgesic, anti-diarrheal, hypoglycemic, CNS antidepressant properties [1-4]. Ethnopharmacology is a branch of pharmaceutical science which deals with the study of such natural sources, particularly of plants for the isolation and identification of bioactive secondary metabolites with desired therapeutic properties. Some therapeutic agents currently in use were derived from plant sources and includes anti-cancer drugs like vincristine, vinblastine and paclitaxel [5]; antimalarial drugs like quinine and artemisinin [6] as well as narcotic analgesics like morphine [7]. The initial stage of the study for the identification of bioactive principles usually involves the preliminary screening of the crude plant extract for its supposed medicinal values [8].

Campsis radicans L. (Family: Bignoniaceae; Bengali name: Kolkephul) is reported as one of the most beautiful flowering plants in the world which is widely distributed in USA, Canada, China, and South Asia [9] . In Bangladesh the plant grows in parks and roadside areas as an ornamental plant [10]. The plant is notable for its showy trumpet-shaped flowers which are very attractive to hummingbirds, and many types of birds. Its traditional medicinal uses includes healing of wounds, treatment of infections caused by Candida, Hemophyllus etc. and anti-itching medication [11]. In china, the plant is well known for its anticoagulant property which is traditionally used for the treatment of abnormal menstruation and dysmenorrhea. Chemical investigation of the aerial parts of $C$. radicans led to the isolation of coumarins such as 8-methoxy furanocoumarin, pabulenone, pereflorin B and 17-methylbothrioclinin [12].

Extensive literature search indicates that there is no scientific report on the biological investigations of the plant to confirm its medicinal properties. Therefore, in this study, the plant $C$. radicans was thoroughly investigated for evaluation of pharmacological potentials by in vitro antioxidant, thrombolytic, membrane-stabilizing and in vivo analgesic, hypoglycemic, anti-diarrheal and CNS antidepressant activities in suitable experimental model.

\section{Materials and methods}

\section{Collection and extraction of plant material}

Leaves with barks of the plant Campsis radicans $\mathrm{L}$. were collected from Curzon Hall, University of Dhaka, Bangladesh during the month of December 2016. The plant was taxonomically identified by the experts of Bangladesh National Herbarium, Mirpur, Dhaka (DACB; Accession No- 43433). The properly cleaned leaves with barks were air-dried and ground to a coarse powder.
The powdered materials were macerated in methanol for few days and finally, filtered through Whatman filter paper number 1 . The filtrate was concentrated using a rotary evaporator (Heidolph, UK) at low temperature $\left(40{ }^{\circ} \mathrm{C}\right)$ and pressure. About $5 \mathrm{~g}$ of the concentrated extract designated as the crude methanol extract of Campsis radicans was subjected to solvent-solvent partitioning following the modified Kupchan method [13] to petroleum-ether (PESF), dichloromethane (DMSF) and ethyl acetate (EASF) soluble fractions. Then the crude extract and its Kupchan fractions were studied separately for the evaluation of their biological activities.

\section{Drugs and reagents}

All regaents and chemicals such as 1,1-diphenyl-2picrylhydrazyl (DPPH), tert-butyl-1-hydroxytoluene (BHT), gallic acid, acetic acid and Tween 80, castor oil were of analytical grade. Ascorbic acid, streptokinase, acetyl salicylic acid, morphine, diclofenac sodium, glibenclamide, fluoxetine, thiopental sodium, castor oil and loperamide were obtained as gifts from Square Pharmaceuticals Limited, Kaliakair, Dhaka and Beximco Phamraceuticals Limited, Tongi, Dhaka.

\section{In vitro studies}

\section{Determination of total phenolic content}

The total phenolic content was determined by the FolinCiocalteau's spectrophotometric method [14, 15]. Here, gallic acid was used as the standard and different concentrations of gallic acid solution were prepared in the range of $0.391 \mu \mathrm{g} / \mathrm{ml}$ and $100 \mu \mathrm{g} / \mathrm{ml} .1 .0 \mathrm{ml}$ plant extract $(2 \mathrm{mg} / \mathrm{ml})$ was mixed with Folin-Ciocalteau's phenol reagent, $2.0 \mathrm{ml}$ of $7.5 \% \mathrm{Na}_{2} \mathrm{CO}_{3}$ solution was then added to the reaction mixture followed by the addition of 13 $\mathrm{ml}$ of deionized distilled water. The mixture was allowed to stand in the dark for $20 \mathrm{~min}$. The absorbance was recorded at $760 \mathrm{~nm}$. A calibration curve was prepared from the data of gallic acid solution and it was used to determine total phenolic content of the plant extracts. The results were expressed as mg of gallic acid equivalent (GAE) per g dry weight extract.

\section{Free radical scavenging by DPPH method}

The DPPH (1,1-diphenyl-2-picrylhydrazyl) radical scavenging activity of PESF, DMSF and EASF on the stable DPPH radical was estimated by the method established by Brand-Williams et al [16]. Briefly, plant extract was dissolved in methanol to produce stock solution of 1.0 $\mathrm{mg} / \mathrm{ml}$. Serial dilution was performed on the stock solution to produce solutions of $0.977 \mu \mathrm{g} / \mathrm{ml}$ to $500 \mu \mathrm{g} / \mathrm{ml}$. To $2 \mathrm{ml}$ of each diluted solution of plant extract, $3 \mathrm{ml}$ of DPPH working solution (prepared in methanol, $20 \mu \mathrm{g} / \mathrm{ml}$ conc.) was added and then incubated in the dark for 30 min. The absorbance was then measured in a UV-Vis 
spectrophotometer (Shimadzu, Japan) at $517 \mathrm{~nm} . \%$ Inhibition of DPPH was calculated and $\mathrm{IC}_{50}$ value $(50 \%$ inhibition concentration) was calculated for each extract by plotting \% inhibition of DPPH against concentration. Tert-Butyl-1-hydroxytoluene (BHT) and ascorbic acid (AA) were used as reference standards.

\section{In vitro thrombolytic activity}

The thrombolytic activity of PESF, DMSF and EASF was evaluated following the method developed by Prasad et al [17] using streptokinase (SK) as standard.

\section{In vitro membrane stabilizing activity}

The membrane stabilizing activity of the plant samples was evaluated by the method described in literature [18] which involved heat- and hypotonic solution-induced hemolysis.

\section{Test animals}

For in vivo biological tests, $4-5$ weeks old Swiss albino mice of either sex were collected from International Center for Diarrheal Disease and Research, Bangladesh (ICDDR, B). They were kept under controlled room temperature $\left(24 \pm 2{ }^{\circ} \mathrm{C}\right.$; relative humidity $\left.60-70 \%\right)$ in a $12 \mathrm{~h}$ light-dark cycle and fed ICDDR, B formulated rodent food and water ad libitum. Food was withdrawn 12 $\mathrm{h}$ before and during the experiment. The experiments were accomplished according to the guide for the care and use of laboratory animals. The protocols for conducting the experiments on the animals were approved by the institutional ethical committee [19].

\section{Study design for in vivo studies}

Swiss albino mice were randomly assigned to eight groups of three animals each for the different experimental models. The first group served as negative control receiving $1 \%$ Tween 80 in normal saline $(10 \mathrm{ml} / \mathrm{kg}$ body weight). The second group served as positive control and was given standard drugs for the respective experiment. The third and fourth groups received PESF (200- and $400 \mathrm{mg} / \mathrm{kg}$ body weight), the fifth and sixth groups received DCM (200- and $400 \mathrm{mg} / \mathrm{kg}$ body weight), and finally seventh and eighth groups received EASF (200- and $400 \mathrm{mg} / \mathrm{kg}$ body weight) of crude methanol extract of $C$. radicans, respectively.

\section{In vivo studies}

\section{Central analgesic activity}

Tail immersion procedure [20] was used to determine the central analgesic activity of the plant extracts. Morphine $(2 \mathrm{mg} / \mathrm{kg}$ body weight) solution prepared in normal saline was administered subcutaneously as the standard. The organic soluble fractions of the methanol of Campsis radicans (200 - and $400 \mathrm{mg} / \mathrm{kg}$ body weight) and the negative control (1\% Tween 80 in normal saline) were administered orally. For the test, $1-2 \mathrm{~cm}$ of tail of the mouse was dipped into a water bath containing warm water maintained a constant temperature of $55^{\circ} \mathrm{C}$. The time taken by the mouse to deflect its tail was recorded before $(0 \mathrm{~min})$ and at $0,30,60$, and $90 \mathrm{~min}$ after administration of the treatments. The \% time elongation was determined using the following equation and this was compared with the standard to evaluate central analgesic activity. The higher the elongation percentage of the group the greater is the group's central analgesic activity.

$$
\% \text { time elongation }=\frac{T_{\text {test }}-T_{\text {control }}}{T_{\text {control }}} \times 100 \%
$$

Here $T_{\text {test }}$ is the average time of tail deflection in the test group and $\mathrm{T}_{\text {control }}$ is the average time of tail deflection in control group.

\section{Peripheral analgesic activity}

Acetic acid-induced writhing test was performed as reported previously [21] to determine the peripheral analgesic activity of $C$. radicans in albino mice. Plant extracts (200 - and $400 \mathrm{mg} / \mathrm{kg}$ body weight) as well as the negative control (1\% Tween 80 in normal saline) and the standard diclofenac sodium $(50 \mathrm{mg} / \mathrm{kg}$ body weight) were administered to the albino mice orally. About 40 min after administration of the sample, $1 \%$ acetic acid $(0.1 \mathrm{ml} / 10 \mathrm{~g}$ body weight $)$ was administered to the experimental animal by intra-peritoneal route to induce writhing. Number of abdominal constrictions i.e. writhes were counted for each group of mice starting from 5 min after the injection of acetic acid up to $10 \mathrm{~min}$ and \% inhibition of writhing was determined according to the following formula to evaluate peripheral analgesic activity:

$$
\text { \%inhibition of writhing }=\frac{W_{\text {test }}-W_{\text {control }}}{W_{\text {control }}} \times 100 \%
$$

Here, $W_{\text {test }}$ refers to the average number of writhing in the test group and $\mathrm{W}_{\text {control }}$ refers to that in the control group.

\section{Hypoglycemic activity}

Hypoglycemic activity of $C$. radicans was determined in albino mice according to the method described in literature [22]. The soluble fractions of crude methanol extract of C. radicans (200- and $400 \mathrm{mg} / \mathrm{kg}$ body weight) and standard glibenclamide (10 mg/ $\mathrm{kg}$ body weight) were administered to the mice orally. $1 \mathrm{~h}$ after the administration, all groups was treated with $10 \%$ glucose solution ( $2 \mathrm{~g} / \mathrm{kg}$ body weight). At 1,2 and $3 \mathrm{~h}$ of glucose administration, the blood was collected from tail vein of 
mice and blood glucose level was measured using a standard glucometer. The hypoglycemic activity of $C$. radicans was reflected by \% reduction of blood glucose level calculated using the formula shown below:

$$
\% \text { reduction in blood glucose }=\frac{B G_{\text {control }}-B G_{\text {test }}}{B G_{\text {control }}} \times 100 \%
$$

Here, $B G_{\text {test }}$ refers to the average blood glucose level in the test group and $\mathrm{BG}_{\text {control }}$ refers to average blood glucose level in the control group.

\section{Anti-diarrheal activity}

Anti-diarrheal activity of $C$. radicans was evaluated by the method of castor oil-induced diarrhea in mice [23]. The test groups received the soluble fractions of crude methanol extract of $C$. radicans at the doses of 200- and $400 \mathrm{mg} / \mathrm{kg}$ body weight while the positive control group received the standard loperamide $(50 \mathrm{mg} / \mathrm{kg}$ body weight) and the negative control group received vehicle (1\% Tween 80 in normal saline) at the dose of $10 \mathrm{ml} / \mathrm{kg}$ body weight orally. The number of diarrheal feces excreted by the mice was observed for up to $4 \mathrm{~h}$ and \% reduction in diarrhea by the plant extract was calculated using the following formula to evaluate antidiarrheal activity:

$$
\text { \%reduction in diarrhea }=\frac{D_{\text {control }}-D_{\text {test }}}{D_{\text {control }}} \times 100 \%
$$

Here, $D_{\text {test }}$ refers to the average number of diarrheal defecation in the test group and $\mathrm{D}_{\text {control }}$ refers to that in control group in the same duration.

\section{CNS antidepressant activity}

The CNS antidepressant activity of $C$. albicans was evaluated by thiopental-induced sleeping time test on Swiss albino mice [24]. The soluble fractions of crude methanol extract of C. radicans (200- and $400 \mathrm{mg} / \mathrm{kg}$ body weight) and standard fluoxetine ( $30 \mathrm{mg} / \mathrm{kg}$ body weight) were administered orally. After passing $30 \mathrm{~min}$, thiopental sodium ( $25 \mathrm{mg} / \mathrm{kg}$ body weight) was administered to each mouse subcutaneously to induce sleep. Then, the sleeping time for each mouse was recorded and the CNS antidepressant activity was evaluated by determining \% inhibition of sleeping time according to following formula:

$$
\text { \%inhibition of sleeping time }=\frac{T_{\text {control }}-T_{\text {test }}}{T_{\text {control }}} \times 100 \%
$$

Here $\mathrm{T}_{\text {test }}$ is the average sleeping time in the test group and $\mathrm{T}_{\text {control }}$ is that in control group.

\section{Statistical analysis}

All values were determined as mean \pm standard error of mean (SEM) whenever possible. When applicable, data was statistically evaluated by means of Dunnett's t-test using GraphPad Prims (version 7) and the $p$ values < 0.05 was considered statistically significant.

\section{Results}

The present study was undertaken to evaluate the DPPH free radical scavenging assay, thrombolytic, membrane stabilizing assay, analgesic, hypoglycemic, anti-diarrheal and CNS antidepressant activities of different organic soluble fractions of the crude methanol extract of $C$. radicans. The results are shown in Tables $1,2,3,4$, and 5 and Figs. 1 and 2.

The comparative study of total phenol content on all $C$. radicans leaf extracts in different solvents was conducted by using the Folin-Ciocalteau's spectrophotometric method. The total phenol content in the extracts was computed from the regression equation $\left(y=0.016 x+0.024, R^{2}=0.997\right)$ of the calibration curve prepared from data of gallic acid solution. The total phenolic contents of plant extracts varied from 6.38 to $60.13 \mathrm{mg}$ of GAE/g of extractives. As shown in the Table 1, the DMSF showed the highest value in total phenol content (60.13 mg of GAE/g of extractives) followed by the PESF $(17.74 \mathrm{mg}$ of $\mathrm{GAE} / \mathrm{gm}$ of extractives).

The antioxidant activities of organic fractions of $C$. radicans extract were determined via measuring the free radical scavenging ability. As shown in Table 1, the EASF showed the highest free radical scavenging activity with $\mathrm{IC}_{50}$ value of $4.69 \mu \mathrm{g} / \mathrm{ml}$ while PESF showed the lowest free radical scavenging activity with $\mathrm{IC}_{50}$ value of $71.82 \mu \mathrm{g} / \mathrm{ml}$. Though the antioxidant potential of organic fractions of $C$. radicans leaf extract was found to be low than those of standard ascorbic acid $\left(\mathrm{IC}_{50}=4.31 \mu \mathrm{g} / \mathrm{ml}\right)$, the study revealed that enhanced antioxidant activity of both the EASF and DMSF may be due to the presence

\begin{tabular}{|c|c|c|c|}
\hline $\begin{array}{l}\text { Test } \\
\text { Sample }\end{array}$ & $\begin{array}{l}\text { Total phenolic } \\
\text { content } \\
\text { (mg of GAE/g of dried extract) }\end{array}$ & $\begin{array}{l}\text { DPPH free radical } \\
\text { scavenging activity } \\
\left(\mathrm{IC}_{50} \mu \mathrm{g} / \mathrm{ml}\right)\end{array}$ & $\begin{array}{l}\% \\
\text { Clot lysis }\end{array}$ \\
\hline PESF & 17.74 & 71.82 & 57.14 \\
\hline DMSF & 60.13 & 8.64 & 37.5 \\
\hline EASF & 6.38 & 4.69 & 49.31 \\
\hline $\mathrm{BHT}$ & - & 17.45 & - \\
\hline $\mathrm{AA}$ & - & 4.31 & - \\
\hline SK & - & - & 68.22 \\
\hline
\end{tabular}

Table 1 Total phenolic content, DPPH free radical scavenging and thrombolytic activities of PESF, DMSF and EASF

Here, PESF, DMSF, EASF = petroleum-ether, dichloromethane, ethyl acetate soluble fraction of crude methanol extract of $C$. radicans, respectively 
Table 2 Analgesic activity of PESF, DMSF and EASF in mice by tail immersion assay

\begin{tabular}{llll}
\hline Treatment & \multicolumn{2}{l}{ \% Time elongation (Mean \pm SEM) } & \\
\cline { 2 - 4 } & After 30 min & After 60 min & After 90 min \\
\hline Morphine (2 mg/kg b.w.) & $75.44 \pm 1.45^{* *}$ & $333.61 \pm 2.34^{* *}$ & $508.32 \pm 11.65^{* *}$ \\
PE (200 mg/kg b.w.) & $72.44 \pm 7.53^{* *}$ & $115.56 \pm 13.01^{* *}$ & $212.93 \pm 20.93^{* *}$ \\
PE (400 mg/kg b.w.) & $63.71 \pm 10.67^{*}$ & $136.42 \pm 16.43^{* *}$ & $237.59 \pm 4.17^{* *}$ \\
DCM (200 mg/kg b.w.) & $61.66 \pm 15.17^{*}$ & $156.63 \pm 3.63^{* *}$ & $179.94 \pm 11.71^{* *}$ \\
DCM (400 mg/kg b.w.) & $85.40 \pm 2.89^{* *}$ & $217.55 \pm 9.73^{* *}$ & $233.73 \pm 32.81^{* *}$ \\
EA (200 mg/kg b.w.) & $43.93 \pm 2.80^{* *}$ & $134.44 \pm 12.99^{* *}$ & $173.70 \pm 7.88^{* *}$ \\
EA (400 mg/kg b.w.) & $75.85 \pm 4.28^{* *}$ & $197.35 \pm 6.34^{* *}$ & $205.50 \pm 13.06^{* *}$ \\
\hline
\end{tabular}

All values by Student's -test, significant at ${ }^{* *} P<0.001,{ }^{*} P<0.05$ and $\mathrm{SEM}=$ standard error mean

of high antiradical phenolic compounds present in these two fractions.

During in vitro thrombolytic activity study, the different solvent fractions of C. radicans extract have prominent thrombolytic activity (Table 1 ). The PESF exhibited highest thrombolytic activity (57.14\% clot lysis), followed by EASF (49.31\%) as compared to standard streptokinase (30,000 I.U.) which showed $68.22 \%$ clot lysis.

The soluble fractions of $C$. radicans leaf extract at concentration of $2.0 \mathrm{mg} / \mathrm{ml}$, significantly protected the lysis of human erythrocyte membrane induced by heat and hypotonic solution, as compared to the standard acetyl salicylic acid (ASA) at the concentration of 0.10 $\mathrm{mg} / \mathrm{ml}$ (Fig. 1). During heat-induced condition, the DMSF and PESF of crude methanol extract of C. radicans demonstrated $53.95 \%$ and $52.17 \%$ inhibition of hemolysis of human RBCs, respectively whereas standard ASA inhibited $42.57 \%$. In hypotonic solution-induced hemolysis, all the plant extractives demonstrated relatively lower activity compared to the extent of inhibition observed during heat-induced condition.

The central analgesic effect of organic soluble fractions and reference drug morphine in albino mice is presented in Table 2. In this test, morphine ( $2 \mathrm{mg} / \mathrm{kg}$ body weight) showed greater activity $(p<0.05)$ compared to the test samples, but all the plant samples at the doses of 200 and $400 \mathrm{mg} / \mathrm{kg}$ body weight (b.w.) induced a significant $(p<0.001)$ decrease in the painful sensation in test animals when compared to untreated control groups in tail immersion method. These results indicate excellent central analgesic activity of the $C$. radicans in the experimental mice. The percent (\%) elongation times were recorded at 30, 60 and $90 \mathrm{~min}$ after administration of drug samples in the albino mice. After $90 \mathrm{~min}$, the PESF exhibited highest elongations as $237.59 \%$ compared to $508.32 \%$ by morphine.

The effect of soluble fractions of $C$. radicans extract on the acetic acid-induced abdominal constrictions in mice is shown in Table 3 . The result shows that the tested soluble fractions (200 and $400 \mathrm{mg} / \mathrm{kg}$ body weight) and the standard drug diclofenac sodium $(2 \mathrm{mg} /$ $\mathrm{kg}$ body weight) significantly $(P<0.001)$ reduced abdominal writhing in mice when compared to the negative control group reducing the mean number of writhing from 17.66 in the negative group to 5.0 by DMSF at the dose of $400 \mathrm{mg} / \mathrm{kg}$ body weight (Table 3). The reduction of abdominal writhing was in a dose-dependent manner. Also the tested soluble fractions of plant extract caused a dose-dependent increase in inhibition of abdominal writhing, increasing it from $0 \%$ in negative control group to $71.70 \pm 2.67 \%, 66.04 \pm 2.67 \%$ and $64.15 \pm 1.54 \%$ by DMSF, EASF and PESF of C. radicans leaf extract, respectively at the dose of $400 \mathrm{mg} / \mathrm{kg}$ body weight.

The preliminary hypoglycemic activity of C. radicans was evaluated in Swiss albino mice by oral glucose tolerance test and the data shown in Table 4 are presented as

Table 3 Analgesic activity of PESF, DMSF and EASF in mice by acetic acid-induced writhing test

\begin{tabular}{lll}
\hline Test group & Mean writhing & \% Inhibition of writhing (mean \pm SEM) \\
\hline Control (1\% Tween 80) & 17.66 & - \\
Diclofenac sodium (50 mg/kg b.w.) & 5.33 & $69.81 \pm 4.08^{* *}$ \\
PESF (200 mg/kg b.w.) & 7.33 & $58.49 \pm 1.54^{* *}$ \\
PESF (400 mg/kg b.w.) & 6.33 & $64.15 \pm 1.54^{* *}$ \\
DMSF (200 mg/kg b.w.) & 8.0 & $54.72 \pm 2.67^{* *}$ \\
DMSF (400 mg/kg b.w.) & 5.0 & $71.70 \pm 2.67^{* *}$ \\
EASF (200 mg/kg b.w.) & 8.33 & $52.83 \pm 5.55^{* *}$ \\
EASF(400 mg/kg b.w.) & 6.0 & $66.04 \pm 2.67^{* *}$ \\
\hline
\end{tabular}

**P $<0.001$; all values expressed as mean \pm SEM 
Table 4 Hypoglycemic activity of PESF, DMSF and EASF in mice oral glucose tolerance test

\begin{tabular}{llll}
\hline Treatment & \multicolumn{2}{l}{ \% Blood glucose reduction } & \\
\cline { 2 - 3 } & After $1 \mathrm{~h}$ & After $2 \mathrm{~h}$ & After $3 \mathrm{~h}$ \\
\hline Glibenclamide (2 mg/kg b.w.) & $33.99 \pm 7.55$ & $24.35 \pm 3.69$ & $39.82 \pm 2.61^{* *}$ \\
PESF (200 mg/kg b.w.) & $9.88 \pm 4.87$ & $52.17 \pm 3.71^{*}$ & $14.16 \pm 3.15^{*}$ \\
PESF (400 mg/kg b.w.) & $19.76 \pm 11.78$ & $53.04 \pm 3.69^{* *}$ & $16.81 \pm 15.65$ \\
DMSF (200 mg/kg b.w.) & $27.27 \pm 10.16$ & $43.48 \pm 2.84^{* *}$ & $43.36 \pm 4.40^{* *}$ \\
DMSF (400 mg/kg b.w.) & $26.48 \pm 6.22$ & $59.13 \pm 3.95^{* *}$ & $18.58 \pm 1.45^{* *}$ \\
EASF (200 mg/kg b.w.) & $34.39 \pm 12.91$ & $43.48 \pm 2.56^{* *}$ & $8.85 \pm 14.61^{*}$ \\
EASF (400 mg/kg b.w.) & $14.62 \pm 7.27$ & $48.70 \pm 4.66^{* *}$ & $30.09 \pm 3.82^{* *}$ \\
\hline
\end{tabular}

${ }^{* *} P<0.01,{ }^{*} P<0.05 ;$ all values expressed as Mean \pm SEM

mean percentage of blood glucose reduction respect to fasting concentration. According to the obtained results, the organic soluble fractions of $C$. radicans leaf extract demonstrate significant $(P<0.05)$ hypoglycemic activity compared to standard glibenclamide and this activity persists up to $2 \mathrm{~h}$ after the oral administration of glucose. The hypoglycemic activity is insignificant at $1 \mathrm{~h}$ but statistically significant at $2 \mathrm{~h}$ mark (Table 4 ). Among all, the DMSF at dose $200 \mathrm{mg} / \mathrm{kg}$ body weight and EASF at dose $400 \mathrm{mg} / \mathrm{kg}$ body weight showed maximum activity which persist up to the $2 \mathrm{~h}$ of treatment. On the other hand, PESF at both doses (200 and $400 \mathrm{mg} / \mathrm{kg}$ body weight) and DMSF at higher dose $(400 \mathrm{mg} / \mathrm{kg})$ lowered blood glucose level in 52.17\%, 53.04\% and 59.13\%, respectively up to $2 \mathrm{~h}$ of treatment and after that started to lose its glucose lowering activity (Table 4).

In castor oil-induced diarrheal model, the PESF, DMSF and EASF demonstrated marked $(P<0.05)$ anti-diarrheal effect in Swiss albino mice (Table 5). Castor oil administration to mice induced diarrhoea for the following $4 \mathrm{~h}$ in the control group. This condition was markedly reduced by standard loperamide (74.96\%) as well as PESF, with the maximum effect (80.06\%) observed at $400 \mathrm{mg} /$ $\mathrm{kg}$ as shown in Table 5. Oral pretreatment of mice with different doses (200 and $400 \mathrm{mg} / \mathrm{kg}$ body weight) of test samples i.e., PESF, DMSF and EASF showed a significant $(p<0.05)$ reduction in the number of diarrheal feces in test animal, with the higher dose of the soluble fraction exhibiting the better effect.

The CNS antidepressant activity was evaluated by thiopental sodium-induced sleeping time test. This test evaluated whether the experimental soluble fractions of C. radicans extract would be able to reduce the duration of sleep caused by thiopental sodium administration in mice. All soluble fractions showed statistically significant $(p<0.01)$ antidepressant activity (Fig. 2).

\section{Discussion}

In our present study the antioxidant, thrombolytic, membrane stabilizing, analgesic, hypoglycemic, anti-diarrheal and CNS antidepressant properties of the organic soluble portions of the methanol extract of Campsis radicans leaves were determined and the results of our study clearly indicates significant antioxidant, thrombolytic, membrane stabilizing, analgesic, hypoglycemic, anti-diarrheal and CNS antidepressant properties.

Both DPPH free radical scavenging and total phenolic content assay methods were employed to determine the antioxidant activity of $C$. radicans. The role of free radicals in pathological manifestations is well known. Antioxidants fight against free radicals before they attack the target biomolecules such as nucleic acids, proteins and lipids, and thereby protect human body from various diseases such as diabetes, atherosclerosis, aging, etc. [25].

Table 5 Anti-diarrheal activity study of PESF, DMSF and EASF by castor oil-induced diarrhea in mice

\begin{tabular}{lllll}
\hline Treatment & \multicolumn{2}{l}{ \% Reduction in the number of diarrheal feces in mice } & & \\
\cline { 2 - 5 } & After 1 h & After $2 \mathrm{~h}$ & After $3 \mathrm{~h}$ & After $4 \mathrm{~h}$ \\
\hline Loperamide (50 mg/kg b.w.) & $100 \pm 0.00^{*}$ & $90.09 \pm 8.17^{* *}$ & $85.65 \pm 5.83^{* *}$ & $74.96 \pm 4.08^{* *}$ \\
PESF (200 mg/kg b.w.) & $75.18 \pm 20.41$ & $79.88 \pm 16.33^{*}$ & $57.17 \pm 10.10^{*}$ & $65.07 \pm 4.08^{* *}$ \\
PESF (400 mg/kg b.w.) & $75.18 \pm 20.41$ & $90.09 \pm 8.17^{* *}$ & $78.59 \pm 0.00^{* *}$ & $80.06 \pm 4.08^{* *}$ \\
DMSF (200 mg/kg b.w.) & $75.18 \pm 20.41$ & $79.98 \pm 8.17^{* *}$ & $57.17 \pm 0.00^{* *}$ & $65.07 \pm 4.08^{* *}$ \\
DMSF (400 mg/kg b.w.) & $24.81 \pm 35.36$ & $60.06 \pm 16.33$ & $50.01 \pm 5.83^{* *}$ & $65.07 \pm 4.08^{* *}$ \\
EASF (200 mg/kg b.w.) & - & $30.03 \pm 8.17$ & $35.76 \pm 10.10$ & $44.98 \pm 8.16^{*}$ \\
EASF (400 mg/kg b.w.) & $75.18 \pm 20.41$ & $69.97 \pm 0.00^{* *}$ & $50.01 \pm 5.83^{* *}$ & $59.97 \pm 4.08^{* *}$
\end{tabular}

${ }^{* *} p<0.01,{ }^{*} p<0.05 ;$ all values expressed as Mean \pm SEM 


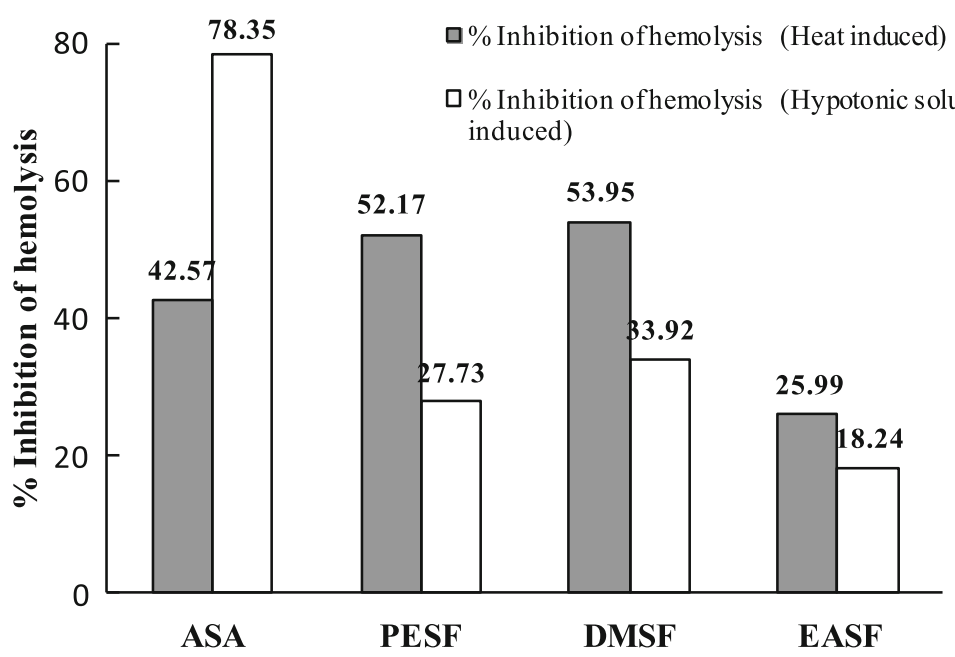

Fig. 1 Membrane stabilizing activities of different organic fractions of C. radicans leaves extract

The test samples showed significant free radical scavenging properties. The total phenolic content of the organic soluble partitionates of the methanol extract of $C$. radicans leaf was determined by using Folin-Ciocalteu reagent and the results have been expressed as gallic acid equivalents. The antioxidant capacity of C. radicans can be attributed to the prevalence of phenolic compounds which act as free radical scavengers [26] due to the presence of hydroxyl group in their aromatic structures [27].

Thrombus formation inside the blood vessels hinders blood flow through the circulatory system leading hypertension, stroke to the heart, anoxia, and so on. Thrombolytic compounds are reported to be effective in the prevention and management of coronary heart diseases and stroke [28, 29]. Previously several research works have been conducted to find out the natural compounds having thrombolytic properties. Some thrombolytic agents obtained by recombinant DNA technology have certain limitations [30,31] while those obtained from plant sources are often perceived as safe because they are natural. Therefore, in our study the thrombolytic potential of soluble fractions of methanol extract of C. radicans leaf was evaluated using streptokinase as reference drug. From the present study it can be demonstrated that our findings may indicate the possibility of developing novel thrombolytic compounds from C. radicans extracts. Further studies are ongoing to isolate and characterize the compounds responsible for thrombolytic activity.

The erythrocyte membrane stability test is based on the fact that a number of non-steroidal anti-inflammatory

\section{Antideprassant activity of $C$. radicans}

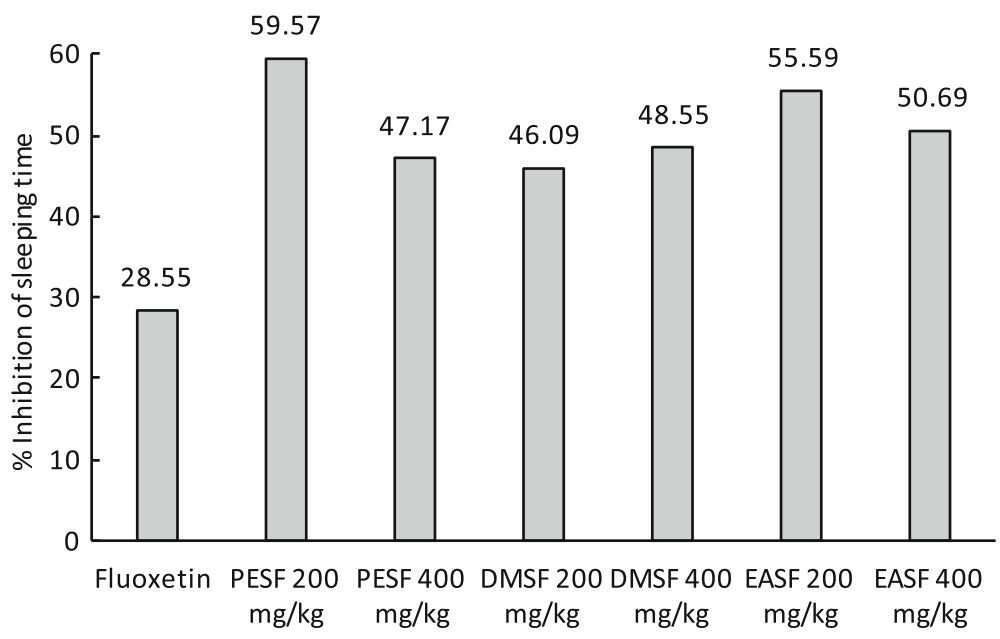

Fig. 2 Antidepressant activities of PESF, DMSF and EASF by thiopental sodium-induced sleeping test 
agents inhibit the rupture of erythrocytes, by stabilizing the cell membrane. Generally, the vitality of cells depends on the integrity of their membranes. Exposure of red blood cell to harmful substances such as heat, hypotonic medium, methyl salicylate results in the disruption of membrane integrity followed by haemolysis and oxidation of haemoglobin. Compounds with RBC membrane stabilizing properties are considered as anti-inflammatory agents for their capability to inhibit the release of phospholipase enzyme, which plays a vital role in inflammatory processes $[32,33]$. In this study, during both heatand hypotonic solution-induced hemolytic assay, the prominent membrane stabilizing activity of $C$. radicans can be attributed to the presence of flavonoids, tannins and other phenolic compounds in the plant extract.

In this study, two tests were employed for the evaluation of analgesic activity of C. radicans, tail immersion test for central analgesic activity and acetic acid-induced writhing for peripheral analgesic activity in mice model. Both tail immersion and acetic acid-induced writhing tests are standard pharmacological models for the assessment of analgesia by natural products [34]. Centrally acting analgesics act by increasing the threshold for pain and altering the physiological response to pain. However, peripherally acting drugs act by inhibiting the generation of pain impulses at the chemoreceptor level [35].

In our study, the tested soluble fractions of $C$. radicans leaf extract at doses of 200 and $400 \mathrm{mg} / \mathrm{kg}$ body weight showed a significant $(p<0.05)$ reduction of pain in Swiss albino mice. The acetic acid-induced writhing is the recommended protocol for evaluating peripheral analgesic activity of medicinal plants. Intraperitoneal administration of acetic acid (1\%) elicits the inflammatory response via the production of prostaglandins specially PGE2 and PGF2 $\alpha$ [36] and histamine [37] in the peritoneal fluid of experimental animal. These endogenous products induce pain and inflammation in the mice. In our study, the soluble fractions at doses of 200 and $400 \mathrm{mg} / \mathrm{kg}$ body weight significantly inhibited the number of abdominal constrictions induced by the injection of acetic acid indicative of the analgesic activity of $C$. radicans by the inhibition of pain mediators. Since all the tested soluble fractions of $C$. radicans leaf extract are inhibiting pain originated by both centrally and peripherally, it can be suggested that they might be acting through both central and peripheral mechanisms. Further phytochemical investigations are required to isolate the responsible components.

According to WHO, hypoglycemic agents of plant source are very important because of their effectiveness, minimal side effects, and relatively low cost. Traditional plant medicines are used throughout the world for treatment of diabetes mellitus [38]. The current research is an earliest screening of organic soluble fractions of $C$. radicans leaf extract at 200 and $400 \mathrm{mg} / \mathrm{kg}$ body weight in mice. In oral glucose tolerance test, experimental extracts at the doses of 200 and $400 \mathrm{mg} / \mathrm{kg}$ body weight exhibited significant hypoglycemic effect in mice which persists up to $2 \mathrm{~h}$ compared to control glibenclamide. It is well known that most medicinal plants have been found to contain phenolic compounds and bioflavonoids that have outstanding antioxidant and antidiabetic properties [39].

The organic fractions of plant extract significantly $(p<$ $0.05)$ inhibited castor oil-induced diarrhea in mice. Ricinoleic acid, the active metabolite of castor oil, causes irritation and inflammation of the gut mucosa which leads to enhanced peristalsis and reduced reabsorption of $\mathrm{Na}^{+}$ ion, $\mathrm{Cl}^{-}$ion, and water from the gut which ultimately induces diarrhea [40]. The anti-diarrheal activity of the experimental plant samples could be mediated by the phytoconstituents like alkaloids, terpenes, glycosides, tannins, and flavonoids present in C. radicans.

The present study demonstrated that the administration of 200 and $400 \mathrm{mg} / \mathrm{kg}$ body weight dose of organic soluble fractions of $C$. radicans leaves showed significant antidepressant properties. The agents which possess CNS antidepressant activity either prolong the time for onset of sleep or decrease the duration of sleep or both [41]. Phytochemical constituents such as flavonoids have been reported to exhibit antidepressant action on the CNS $[42,43]$.

\section{Conclusion}

Based on our preliminary screenings it can be concluded that the petroleum-ether, dichloromethane, and ethyl acetate soluble fraction of $C$. radicans leaf (with bark) extract exhibits significant antioxidant, thrombolytic, membrane-stabilizing, analgesic, hypoglycemic, antidiarrheal and CNS antidepressant activities. However further studies are required to find out the bioactive compounds from $C$. radicans leaf responsible for these pharmacological properties.

\section{Acknowledgements \\ The authors are grateful to Bangladesh National Herbarium, Mirpur, Dhaka for plant identification.}

\section{Authors' contributions}

$\mathrm{Ml}$ and TJ participated in the conduction of the experiments. Data interpretation and analysis were done by MI, MAR and MRH. MRK, MI participated in drafting the manuscript. MRK, MAR and MRH finally revised the manuscript for important intellectual content. MRH supervised and designed the study and corrected all versions of the manuscript. All authors read and approved the final manuscript.

\section{Funding}

University Grants Commission (Award Number: Reg./Admin-3/59119).

\section{Availability of data and materials}

The datasets supporting the conclusions of this article are included within the article. 


\section{Ethics approval}

All experiments were performed according to the ethical standards laid down in the Declaration of Helsinki 2013. Animals were handled and treated according to the principles of the Swiss Academy of Medical Sciences and Swiss Academy of Sciences. Animals were euthanized according to the Guidelines for the Euthanasia of Animals: 2013 edition.

\section{Consent for publication}

Not applicable.

\section{Competing interests}

The authors declare that they have no competing interests.

Received: 14 May 2019 Accepted: 11 December 2019 Published online: 17 December 2019

\section{References}

1. Cragg GM, Newman DJ. Natural products: a continuing source of novel drug leads. BBA. 1830;2013:3670-95.

2. Siddiqui AA, Iram F, Siddiqui S, Sahu K. Role of natural products in drug discovery process. Int J Drug Dev Res. 2014;6:172-204.

3. Patwardhan B. Ethnopharmacology and drug discovery. J Ethnopharmacol. 2005;100:50-2

4. Gurib-Fakim A. Medicinal plants: traditions of yesterday and drugs of tomorrow. Mol Asp Med. 2006:27:1-93.

5. Cragg GM, Newman DJ. Plants as a source of anti-cancer agents. J Ethnopharmacol. 2005;100:72-9.

6. Rates SMK. Plants as source of drugs. Toxicon. 2001;39:603-13.

7. Queiroz EF, Wolfender JL, Hostettmann K. Modern approaches in the search for new lead anti-parasite compounds for higher plants. Curr Drug Targets. 2009;10:202-11.

8. Katiyar C, Gupta A, Kanjilal S, Katiyar S. Drug discovery from plant sources: an integrated approach. Ayu. 2012;33:10-9.

9. Wen J, Jansen RK. Morphological and molecular comparisons of Campsis grandiflora and C. radicans (Bignoniaceae), an eastern Asian and eastern north American vicariad species pair. Plant Syst Evol. 1995:196:173-83.

10. Uddin MZ, Hassan MA. Plant diversity of Dhaka University campus. Bangladesh J Asiat Soc Bangladesh Sci. 2016;42:49-68.

11. Michael M. Medicinal Plants of the Desert and Canyon West; 1989. p. 124.

12. Hashem FA. Investigation of free radical scavenging activity by ESR for coumarins isolated from Tecoma radicans. J Med Sci. 2007:7:1027-32.

13. Van-Wagenen BC, Larsen R, Cardellina JH, Randazzo D, Lidert ZC, Swithenbank C. Ulosantion, a potent insecticide from the sponge Ulosa ruetzleri. J Organomet Chem. 1993:58:335-7.

14. Singleton VL, Rossi JA. Calorimetry of total phenolics with phosphomolybdic phosphotungstic acid reagents. Am J Enol Vitic. 1965;16:144-58.

15. Saeed N, Khan MR, Shabbir M. Antioxidant activity, total phenolic and total flavonoid contents of whole plant extracts Torilis leptophy lla L. BMC Complement Altern Med. 2012:12:221.

16. Brand-William W, Cuvelier ME, Berset C. Use of free radical method to evaluate antioxidant activity. Lebensm-Wiss-U-Technol. 1995;28:25-30.

17. Prasad S, Kashyap RS, Deopujari JY, Purohit HJ, Taori GM, Daginawala HF. Development of an In vitro model to study clot lysis activity of thrombolytic drugs. Thromb J. 2006:4:14

18. Shinde UA, Phadke AS, Nair AM, Mungantiwar AA, Dikshit VJ, Saraf MN. Membrane stabilizing activity-a possible mechanism of action for the antiinflammatory activity of Cedrus deodara wood oil. Fitoterapia. 1999;70:251-7.

19. Zimmermann M. Ethical guidelines for investigations of experimental pain in conscious animals. Pain. 1983;16:109-10.

20. Ezeja Ml, Omeh YS, Ezeigbo II, Ekechukwu A. Evaluation of the analgesic activity of the methanolic stem bark extract of Dialium guineense (wild). Ann Med Health Sci Res. 2011;1:55-62.

21. Koster $R$, Anderson $M$, De Beer EJ. Acetic acid for analgesic screening. Fed Proc. 1959;18:412-6.

22. Babu PR, Rama RD, Prasada RM, Kanth JVK, Srinivasulu M, Hareesh V. Hypoglycemic activity of methanolic extract of Talinum triagulare leaves in normal and streptozotocin induced diabetic rats. J Appl Pharm Sci. 2012;02:197-201.

23. Shoba FG, Thomas M. Study of antidiarrhoeal activity of four medicinal plants in castor oil induced diarrhea. J Ethnopharmacol. 2001;76:73-6.
24. Ashok Kumar BS, Lakshman K, Velmurugan C, Sridhar SM, Gopisetty S. Antidepressant activity of methanolic extract of Amaranthus spinosus. Basic Clin Neurosci. 2014;5:11-7.

25. Harman D. Free radical theory of aging. Current status. Amsterdam: Elsevier; 1998. p. 3-7.

26. Shukla S, Mehta A, John J, Singh S, Mehta P, Vyas SP. Antioxidant activity and total phenolic content of ethanolic extract of Caesalpinia bonducella seeds. Food Chem Toxicol. 2009;47:1848-51.

27. Villano D, Fernández-Pachón MS, Moyá ML, Troncoso AM, Garcia-Parrilla MC. Radical scavenging ability of polyphenolic compounds towards DPPH free radical. Talanta. 2007:71:230-5.

28. Ratnasooriya WD, Fernando TSP, Madubashini PP. In vitro thrombolytic activity of Sri Lankan black tea, Camellia sinensis (L). Kuntze J Nat Sci Found. 2008;36:179-81.

29. Bazzano LA, He J, Ogden LG, Loria CM, Vupputuri S, Myers L, Whelton PK. Fruit and vegetable intake and risk of cardiovascular disease in US adults: the first national health and nutrition examination survey epidemiologic follow-up study. Am J Clin Nutr. 2002;76:93-9.

30. Baruah DB, Dash RN, Chaudhari MR, Kadam SS. Plasminogen activators: a comparison. Vasc Pharmacol. 2006:44:1-9.

31. Capstick T, Henry MT. Efficacy of thrombolytic agents in the treatment of pulmonary embolism. Eur Res. 2005;26:864-74.

32. Kosala K, Widodo MA, Santoso S, Karyono S. In vitro and In vivo antiinflammatory activities of Coptosapelta flavescens Korth root's methanol extract. J Applied Pharm Sci. 2018;8:042-8.

33. Anosike CA, Obidoa O, Ezeanyika LU. Membrane stabilization as a mechanism of the anti-inflammatory activity of methanol extract of garden egg (Solanum aethiopicum). DARU J Pharm Sci. 2012;20:76.

34. Hiruma-Lima CA, Gracioso JS, Bighetti EJB, Germonsén RL, Souza Brito ARM. The juice of fresh leaves of Boerhaavia diffusa L. (Nyctaginaceae) markedly reduces pain in mice. J Ethnopharmacol. 2000;71:267-74.

35. Shreedhara C, Vaidya V, Vagdevi H, Latha K, Muralikrishna K, Krupanidhi A. Screening of Bauhinia purpurea Linn. For analgesic and anti-inflammatory activities. Indian J Pharm. 2009;41:75-9.

36. Sani YM, Musa AM, Pateh UU, Haruna AK, Yaro AH, Sani MB, et al. Phytochemical screening and preliminary evaluation of analgesic and antiinflammatory activities of the methanol root extract of Cissus polyantha. Bayero J Pure Appl Sci. 2014;7:19-23.

37. Serafini MR, Santos RC, Guimaraes AG, dos JPA S, da Conceicao Santos AD, Alves IA, et al. Morinda citrifolia Linn leaf extract possess antioxidant activities and reduces nociceptive behavior and leukocyte migration. J Med Food. 2011:14:1159-66.

38. Shetti A, Kaliwal BB. Hypoglycemic activity of ethanolic leaf extract of Phyllanthus amarus in alloxan induced diabetic mice. European J Exp Biol. 2015;5:26-9

39. Khatun MH, Nesa ML, Islam R, Ripa FA, Mamun A, Kadir S. 2014. Antidiabetic and antidiarrheal effects of the methanolic extract of Phyllanthus reticulates leaves in mice. Asian Pac J Reprod. 2014:3:121-7.

40. Gutierrez SP, Mendoza DZ, Peredo CS, Sanchez OS, Sanchez MAZ Evaluation of the anti-diarrheal activity of Salvia connivens. Pharm Biol. 2014; $52: 1467-70$

41. Nyeem MAB, Alam MA, Awal MA, Mostofa M, Uddin SJ, Islam N, Rouf R. CNS depressant effect of the crude ethanolic extract of the flowering tops of Rosa damascena. Iranian J Pharmacol Ther. 2006;5:171-4.

42. Hossain MM, Biva IJ, Jahangir R, Vhuiyan MMI. CNS depressant and analgesic activity of Aphanamixis polystachya (wall.) parker leaf extract in mice. Afr J Pharm Pharmacol. 2009:3:282-6.

43. Noldner M, Schotz K. Rutin is essential for the antidepressant activity of Hypericum perforatum extracts in the forced swimming test. Planta Med. 2002;68:577-80

\section{Publisher's Note}

Springer Nature remains neutral with regard to jurisdictional claims in published maps and institutional affiliations. 